\title{
Analysis of Determinants of Private Investment in Ethiopia
}

\author{
Mr. Amenu Daba Waktola (MSc.) \\ Wollega University, Department of Economics, Nekemte, Ethiopia
}

\begin{abstract}
To make private investment more attractive, most African countries have liberalized market and attempted to create enabling environment in recent decades. Ethiopia, like many African countries, took some steps towards liberalizing market and the macroeconomic regime as well as introducing some measures aimed at improving the investment regulatory framework. This study analyses the determinants of private investment in Ethiopia using a time series analysis over the period of 1975 to 2009.The study gave an extensive account of the theoretical explanation of private investment as well as reviewing the policy regimes, the investment regulatory framework and institutional set up in the country over the study period. It also undertakes empirical analysis to establish the determining factors of private investment in Ethiopia. Our findings show that growth rate of real GDP, availability of credit, and public investment among others, have positive impact on private investment. On the other hand, macroeconomic instability (liberalization), lending rate, and consumer price index (CPI) have negative impact on private investment. The results suggest that policies that address only some components of macroeconomic instability may not be enough to revive private investment. Thus, the findings imply that liberalization of the market and regulatory regimes, stable macroeconomic and political environment, and major improvements in infrastructure are essential to attract private investors to Ethiopia.
\end{abstract}

DOI: $10.7176 / \mathrm{JESD} / 12-7-03$

Publication date: April $30^{\text {th }} 2021$

\section{INTRODUCTION}

One of the fundamental questions of all developing countries is how to get their economic growth faster. Among a number of alternative factors, that boosts economic growth, investment play important role. Investment can be made either by public or by the private sector.

The idea of developing private sector as an alternative development strategy to improve economic growth and reduce poverty in developing countries emerged in late 1980's. The International Monetary Fund (IMF) and World Bank through International Financial Corporation (IFC) are the forerunners of this strategy in many developing countries. Recent evidence on economic development indicates that private sector, in effective with the public sector, has the way to overcome poverty in Africa. (Gutierrez Z., 2005)

Among the main way that private sector participate on economic development is through private investment, since investment may be define as expenditure in capital goods. (World book, 1992)

Investment is an instrument, which has a great role in the development of economy and especially in LDC's like Ethiopia. This is because of investment is mainly the way through to bring employment opportunities, efficiently uses of the domestic resources, large-scale production, specialization and the like, which is not fulfilled in developing counties. (Befekadu, 1994/2000)

Private investment is led by market forces and thus more efficient than public investment. Public investment is usually through national planning in which it is difficult to address a single issue in the economy. Nevertheless, in the case of private investment as they led market forces and their mainly goal is profit maximization, every specific issues are likely to be addressed and thus higher efficiency in resources mobilization and allocation can be achieved. Private investment is although very important economic ideology in bringing economic development its working is determine by different socio-economic, environmental and political factors. These different factors have either positive or negative effects on private investment. That is, because of some change in some factors, private investment may become less efficient, as negative effects, or on the other hand because of positive changes in some of the determinants, private investment may be encouraged and results that are more efficient can be achieve. (Apple Yard, 2006)

Therefore, in order to study the effect of private investment on the performance of an economy, we need to identify first the factors that are affecting it. By doing so, we will be able to understand why and how changes in private investment occurred and set possible remedies to correct prevailing problem, if any. As we can see that, there are different characteristics or effects of private investment on an economy in different nations or regions. Moreover, this difference is attributing to different determinants involved that are specific to different countries or regions as result of specific economic policies or political ideologies.

When we see in case of Ethiopia, private investment in Ethiopia has been changing with the change of government due to change in ideological outlook they follow, the so-called economic system of each regime. During the period prior to the 1974 revolution known as feudo - capitalistic economic system, there was an encouragement of private sector participation in economic development. (Taye, 2005) 
The issuance of the commercial code in 1960 was a clear indication of the government to encourage domestic and foreign entrepreneurs. Tax incentives and other encouragement provided for foreign investors by giving less importance to domestic private investment. Following the 1974 revolution or during the Derg regime, the centrally planned command economy came up with nationalization of most industries and government control and ownership of all economic activities. Consequently, foreign investors who owned and operated most of the industries be left out and domestic private investment virtually closed. This brought the doomsday for private investment. After elapsed of more than one and half decades, the government declared a mixed economy in which encourages private sector once again. With the fall of communism and emergence of global economy, beginning form 1991, change in economic and political condition happened all over the World. At the same period similar event happened in Ethiopia following the downfall of military government and the new government presently called Ethiopia People's Revolutionary Democratic Front (EPRDF) Adopted market oriented economy in 1992. (Samson, 2002).

The new government has introduced a number of reforms to boost the role of private sector as owner of productive resources. In addition, considerable proportion of total approved investment projects fail to implement due to several reasons in which many of them are attributes to the negative effects of determinants of private investment. (Befekadu, 1999/2000).

Technology, higher employment, low level of poverty, and others, which are mostly common not yet, attained in Ethiopia economy, where long-term solution is can be reach through investment.

\section{Statements of the problem}

Investment is the main ingredient to bring economic growth in both developed and developing countries as investment has a direct and positive relationship with GDP. Among many types of investment, the expansion of private investment has major role to play in economic growth including alleviation of poverty increasing socioeconomic, capital and good services. Recent study shows that, private investment is more related to with growth that public investment. That is the conclusion of studies in 50 developing countries from $1970-1998$ that examine the relationship between private and public investment, growth rate, and income level. (Bouton and Sumlinski; 2000)

For example, in the USA in 1989 the share of growth fixed capital formation to GDP was 19.4\%, average proportion of growth fixed capital formation to GDP form the year 1998

To 2003 was $19.28 \%$. In the same year, average growth GDP was $4.704 \%$ while the average growth rate of growth fixed capital formation was 3.64\% (IFC, 2005).

From this information, we can see that growth rate of investment and growth rate of GDP closely related in U.S.A.

In the second half of 1990's, Sub - Sahara Africa (SSA) has experienced the beginning of an economic turnaround. Reversing trend since the late 1970's, the region has realized positive real GDP per capita over a sustained period from 1995 to 1997, excluding oil producer and South Africa, this trend continued in to 1998. Most countries on the continents have substantially liberalized their economic since the 1980's, the result being a greater reliance on the private sector as engine of growth. Because of these reforms, the climate for private investors and the general economic health of most African countries has greatly improved. This leads to resumption of type of broad based economic growth that that both addresses poverty alleviation and provide an attraction for private investors. (J. Emery et al., 2003:P10)

In addition, Econometric evidence (Beddier, 1999: Ghura and Hzdj; Michael, 1996; Glura, 1997) indicates that private investment has more favorable effect on growth rates than government investment probably because private investment is more efficient and less closely associated with corruption. It estimated that the ratio of private to GDP in SSA countries which as experienced poor rate of growth in 1990's was less than 10\%, compared with 16\% in Latin America, 18-10 in advanced countries and 16.5\% in newly industrialized countries in Asia. (Hernandez - Cata, 2000)

When we come to Ethiopia, the level of private investment during 1975/76 - 2009/10 was fluctuation. During the period of 1975 - 1989 the share of private investment to total domestic investment has declined in comparison to the share during the pre 1975 and post 1990 periods. In 1974, the share of private investment to total investment was 39.5 and it dropped to $11.7 \%$ in 1989 and private investment, increasing slightly in 1990 and 1991 as the Derg regime started reform early in 1989 and proclaimed a mixed economy in 1990. The rate of private investment continued to rise on average since 1992 due to change in economic policies by transitional government and present government of Ethiopia which emphasized market oriented principle that encourage private sector. (Workie, 1997)

As private investment is a very important variable for economic growth, it is determinant also becomes a policy focus. With this regard, interest rate, exchange rate, inflation, public investment, real income, budget deficit, shortage of finance, shortage of infrastructure and other factor can mentioned as the factor that determine and constrain private investment. (Hiywot, 1998) 
Furthermore, to motive the investors; price and market for goods and services have liberalized; access to land is through a lease system, quantitative restriction on imports commodities first reducer. Because of policy change and incentive to development of private sector has been showing improvement in Ethiopia of current year. The number of investment project has been increase form by 1.2 million to 573.6 billion over period 1992 to 2008. On average taking form, the year 1998 to 2001 investments was $4.36 \%$ and GDP was growing on average at $5.78 \%$. (EIA, 2008)

Based on above data, investment especially private investment has very influential role in Ethiopia economy. However, it shows a low performance when compared with developed countries like U.S.A. In addition to this EIA planned to attract between 1992 - January 2010, about 13.751-investment project. However, out of this only about 13.154 is licensed, even from those licensed investment projects all of them are not implemented. Out of this, only $21 \%$ are implemented and other $11.8 \%$ and $67.5 \%$ investment projects are under implementation and pre implementation stage respectively. This shows the low performance of private investment in Ethiopia. (NBE, 2010)

To understand the main causes of low performance of investment in Ethiopia; the core points to be focuses are the determinants of the factor that affect its performance.

Therefore, the main points of this paper is to answer the following questions.

* What are the main causes of low performance of investment in Ethiopia?

* What are the determinants of private investment in Ethiopia?

* What are the different economic variables that affect private investment?

* What is the affect of this variable on private investment?

* What/how are the trends of private investment in Ethiopia?

Thus, in this paper we will try to understand and undertake a system study on private investment climate after the reform and try to answer the above fundamental questions.

\section{Objectives of the Study}

General Objective

The primary objective of the study is to understand the determinants of private investment in Ethiopia between 1975 and 2009.

\section{Specific Objectives}

* To investigate the performance of private investment in Ethiopia based on empirical facts

* To identify the impact of the government policy on private investors

* To evaluate the pre-reform and current trends of private investment performance

* To suggest policy recommendation that might solve the problem of low performance of private investment in Ethiopia

* To analyses the determents of private investment using econometrics model

\section{Research Methodology}

\subsection{Descriptive Data Analysis and Presentation}

\subsubsection{Trend of Private investment during Derg period (1975-1991)}

The policy of the Derg was favorable to public economy. Before, the Derg regime the Ethiopian economy was a type of mixed economy where private and the public investors coexisted. Both sectors considered equally important and complements. However, the actual level of private investment activities and its employment creation was too low compared with other developing countries.

However, after downfall of Imperial government the provisional Military Government of socialist Ethiopia changed the course of development from market-oriented mixed economy to command economy. To this effect, a decree was enacted in 1975, which nationalized almost all of medium and large-scale industries that were owned by private sectors. Moreover, it put restriction on new investment and other existing small-scale industries in which they cannot pass capital ceiling of 500,000 birr. Moreover, investors were not allowed to have license for more than one line of business or even to establish a branch. The tax system was also very discouraging for private investment.

Business income over birr 36,000 per annual was subject to $89 \%$ marginal rate of tax, which was introduced with a view of income redistribution. Interest rate was also higher for private borrowers relative to public enterprises and cooperative. As a policy was restrictive for private sector development, private investment as a ratio of GDP was very low. In addition, the major change under taken by the Derg government were, abolition of private ownership of land in rural and urban areas nationalization of extra dueling, major enterprises in manufacturing industries, banking and insurance and so on. These policies severally hampered the potential for expansion of investment sector during the Derg regime by incapacitating the private investment activities. However, after the collapse of socialism in Eastern Europe and later in the former Soviet Union, the regime tried to introduce some economic liberalization by way of introducing a mixed economic policy in 1990. A number of constraints for private sector development were reconsidered. However, the encouraging measurement was not 
materialized due to misguided policy; economic mismanagement in the form of inefficient management, bureaucratic red-tape, embezzlement of public funds, the protracted civil war, unfavorable balance of payment, shortage of foreign exchange and the absence of inter-sectoral coordination were some of the factor for the downfall of the reform (Tadele and Ayele, 2002/03).

Figure 3.1 Trend of private investment during Derg regime (1975-1991)

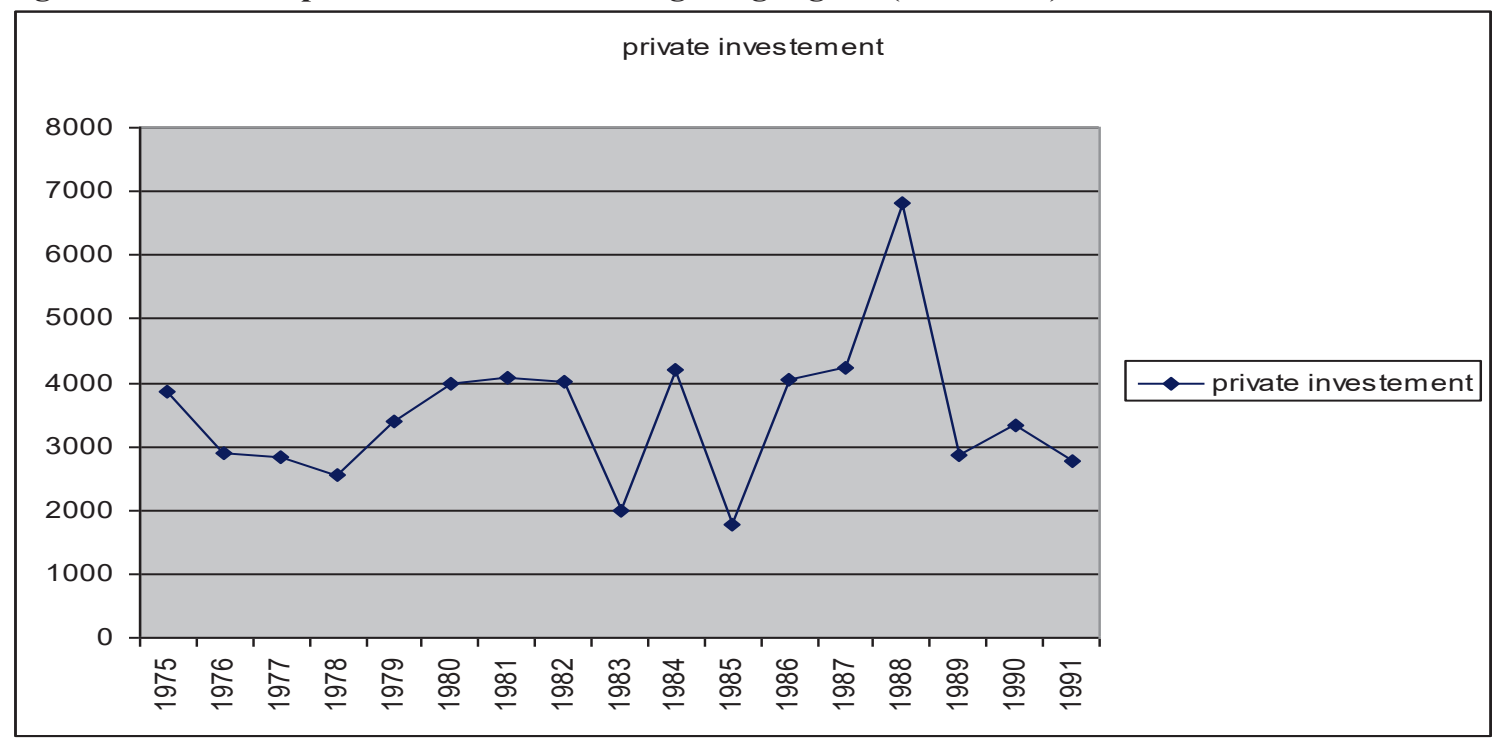

Source: EIA, 2011

As we see from the graph above the trend of private investment during Derg regime shows that private investment does not play a great role in determining national output due to unfavorable investment policy and climate. However, after 1985 it starts to increase due to economic change i.e. mixed economy and starts to decrease due to high taxation on imported good since 1988.

\subsection{Trends and performance of private investment post 1991 period}

Following the collapse of the Derg regime, various political forces established transitional government of Ethiopia (TGE).

Analyzing the major cause of economic crisis during the previous regime the transition period of economic policy "the system denied individuals to own and manage economic activities and the wrong polices that were pursued generally discouraged private investors from engaging in productive activities" (Key Mesrak, 1998).

The TGE sought to rationalize its role in the economy while enhancing the active participation of the private investment. The objective of economic policy of TGE were

* To replace the command economy in to market economy

* To enhance popular participation in the economic activities and decision making process by ensuring control over resources by regional authority

* To increase and diversity export

* To put the utmost emphasis on the agricultural sector through over all development strategy

* To perform the structural adjustment of the economy

After the completion of the transitional period in accordance with the general election results, the majority of the parliament seats went to the EPRDF, which is the current government. After seizure of the power, the EPDRF has made rumerous pronouncements indicating its interest to attract private investment. 
Figure 3.2 Trend of private investment post 1991

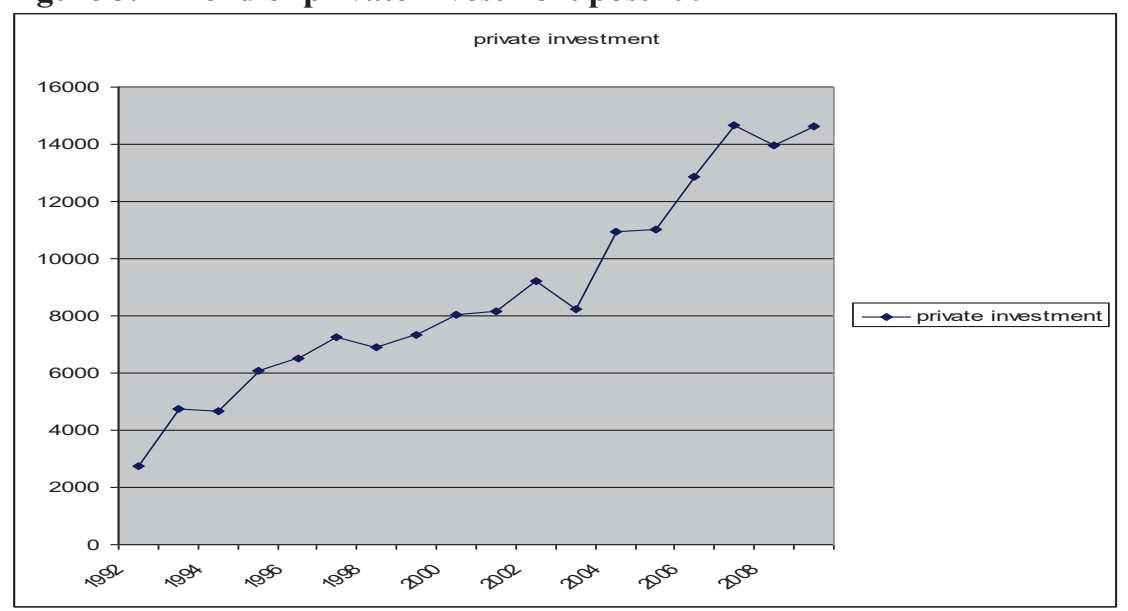

Source: EIA, 2011

The above figure shows that the trend of private investment have a great role on national economy and increase thought the year due to good investment climate for the investor and suitable investment policy. Nevertheless, in 2004, the trend shows that there is a downfall of private investment due to high inflationary rate and then starts to rise.

Because of different changes in policy, the participation of private investment in Ethiopia increased. When we see EIA and regional investment offices licensed some data between 1992 to Jan. 2011 a total of 51,464investment project. The planned capital for these investment projects is 906,677,142 birr. From these planned capitals 2,445,630 is expect to create permanently employment while 4,708,360 are creating temporary employment opportunities when they became operational. Out of these.2723 investment, projects are implemented with planned capital of 79,317.874mill investment projects, licensed are operational with planned capital of 54,636.069mill and 43,020 investment project licensed are pre-implemented with planned capital of 772,723.2mill. (EIA, 2011)

Table 3.1 Summary of Licensed all Investment Projects by Investment Type and Status Since, 1992 -

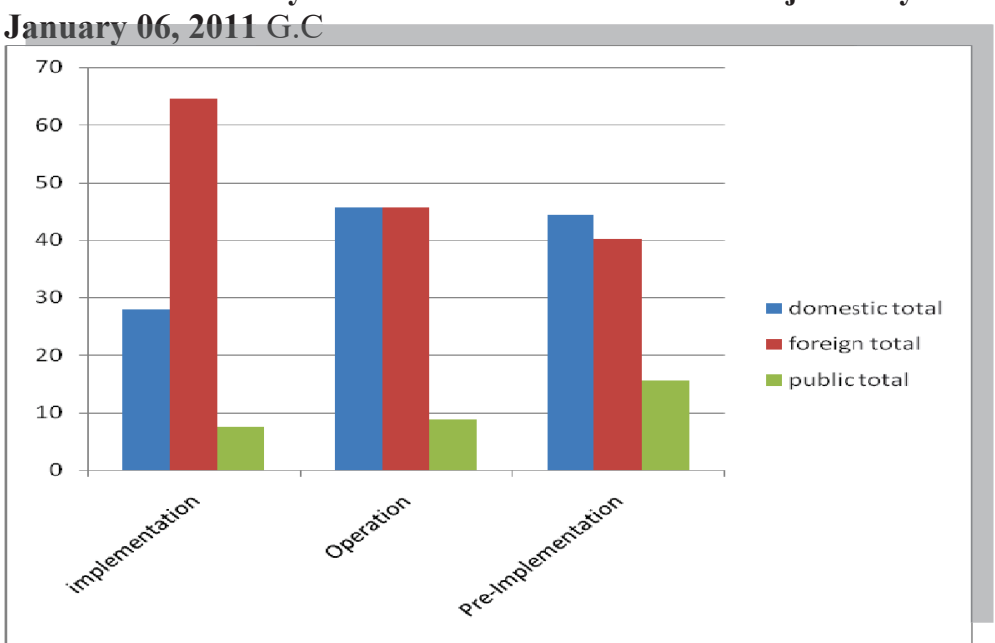

Source: EIA, 2011

From above table we understand that, because of change in economic system i.e. liberalized and market oriented economy and various incentives for private investors

(Both domestic and foreigners), the number of investment project per percentage of number of licensed investment capital projects can increase. To see it clearly let us see the figure below. 
Figure 3.3 Percentage distribution of investment project per share of capital (From 1992-jan.,2011)

\section{Investment Type shareof capital(\%)}

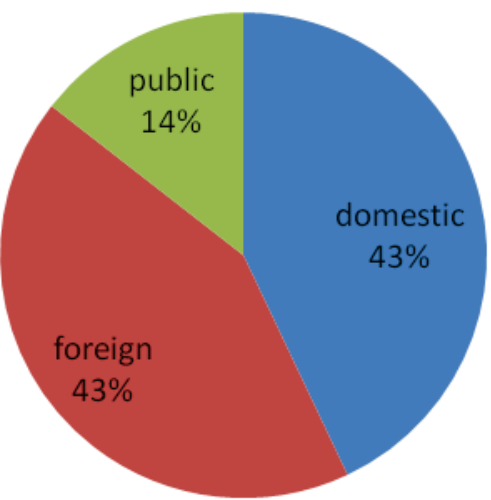

Source EIA, 2011

From the below fig 3.2, we can see that, the distribution of investment project linked to domestic foreign and public investment from 1992 to Jan 2011 are 43,495 (84.7\%), 7859 (15.3\%) and110 (0.2\%) respectively. In terms of capital distribution birr 389, 403, 212, (50.2\%), 385,974,340 (49.8\%) and 131,299,590 (16.7\%) are domestic, foreign and public investment respectively. From this, we can conclude that domestic and foreign have relatively higher capital per project as compared to public investment. This is due to different changes of policy in Ethiopia, government provides varies incentive and conducive environment for both domestic and foreign investors.

Figure 3.4 Percentage distribution of investment project capital (1992- Jan. 2011)

\begin{tabular}{|c|c|c|c|c|c|c|}
\hline \multirow[b]{2}{*}{$\begin{array}{l}\text { Investment } \\
\text { Type }\end{array}$} & \multirow{2}{*}{$\begin{array}{l}\text { Implementation } \\
\text { Capital in '000' } \\
\text { Birr }\end{array}$} & \multirow[b]{2}{*}{$\begin{array}{l}\text { Share of } \\
\text { capital }(\%)\end{array}$} & \multirow{2}{*}{$\begin{array}{l}\text { Operation } \\
\text { Capital in '000' } \\
\text { Birr }\end{array}$} & \multirow{2}{*}{$\begin{array}{l}\text { Share } \\
\text { of } \\
\text { capital } \\
(\%)\end{array}$} & Pre-Implementation & \multirow[b]{2}{*}{$\begin{array}{l}\text { Share of } \\
\text { capital } \\
(\%)\end{array}$} \\
\hline & & & & & $\begin{array}{l}\text { Capital in '000' } \\
\text { Birr }\end{array}$ & \\
\hline domestic total & $22,150,879$ & 28 & $24,909,458$ & 46 & $342,342,876$ & 44.303429 \\
\hline Foreign total & $51,221,881$ & 65 & $24,959,408$ & 46 & $309,793,050$ & 40.091077 \\
\hline public total & $5,945,114$ & 7 & $4,767,202$ & 9 & $120,587,274$ & 15.605494 \\
\hline Grand total & $79,317,874$ & 100 & $54,636,069$ & 100 & $772,723,200$ & 100 \\
\hline
\end{tabular}

Source: EIA, 2011

\subsection{Regional and Sectoral distribution of Private Investment}

\subsubsection{Regional distribution}

Looking by regional distribution of all investment project from 1992 Jan, 2011, Addis Ababa takes the largest share with 21,818, (42.4\%) projects, followed by Oromia, Amhara, SNNPR and Tigray regions with 12,346 $(23.99 \%), 5444(10.38 \%), 4,645(9.98 \%)$ and 2,842 (5.5\%) respectively. The remaining 4,369 ((7.53\%) projects are attributed to the other regional of the total investment capital, of the all investment project licensed, Addis Ababa, Oromia, Multiregional, Amhara and Tigray share 35.8\%, 26.6\%, 12.2\%, 10.05\% and 4.09\% respectively (see annex A3 ). 
Table 3.2 Summary of Licensed all Investment Projects by Region and Status Since, 1992 - January 06, 2011 G.C

\begin{tabular}{|l|l|l|l|l|l|}
\hline Region & $\begin{array}{l}\text { No. } \\
\text { Project }\end{array}$ & $\begin{array}{l}\text { Capital in '000' } \\
\text { Birr }\end{array}$ & $\begin{array}{l}\text { Per. } \\
\text { Emp. }\end{array}$ & $\begin{array}{l}\text { Temp. } \\
\text { Emp. }\end{array}$ & $\begin{array}{l}\text { Share of capital } \\
\text { in(\%) }\end{array}$ \\
\hline Addis Ababa & 21,818 & $324,475,444$ & 742,017 & 926,201 & 35.78731929 \\
\hline Afar & 216 & $14,710,248$ & 20,789 & 89,757 & 1.622435055 \\
\hline Amhara & 5,444 & $91,105,059$ & 270,955 & 757,867 & 10.048236 \\
\hline B.Gumz & 657 & $6,192,007$ & 20,064 & 110,601 & 0.682934058 \\
\hline Dire Dawa & 1,442 & $35,135,953$ & 46,270 & 45,530 & 3.875244213 \\
\hline Gambella & 236 & $7,436,617$ & 18,180 & 102,197 & 0.82020567 \\
\hline Harari & 435 & $1,007,157$ & 9,342 & 1,972 & 0.111082238 \\
\hline Multiregional & 1,170 & $110,450,250$ & 388,691 & 525,549 & 12.18187209 \\
\hline Oromia & 12,346 & $240,798,237$ & 642,552 & $1,115,920$ & 26.5583222 \\
\hline SNNPR & 4,645 & $36,137,084$ & 175,750 & 560,505 & 3.985661772 \\
\hline Somali & 213 & $2,157,146$ & 8,370 & 7,069 & 0.237917752 \\
\hline Tigray & 2,842 & $37,071,940$ & 102,650 & 465,192 & 4.088769656 \\
\hline Grand Total & 51,464 & $906,677,142$ & $2,445,630$ & $4,708,360$ & 100 \\
\hline Source: & & & & \\
\hline
\end{tabular}

Source: EIA, 2011

From the above table 3.2, we understand that there is unbalanced regional distribution of investments. The main explanation for such unfair distribution of investment projects among regions could be due to the problem of basic infrastructure like telecommunication, road, water, health centers, and lack of market for the private investors in other region and lack of stable socio-political conditions.

\subsubsection{Sectoral distribution}

Considering by sector, manufacturing accounted for about $25.6 \%$ of the total number of all licensed investment project, followed by real estate, renting and business activates (23.44\%), Agriculture (19.6\%), hotel (including resort hotels, motels and lodges) and restaurants $(9.46 \%)$ and construction $(7.92 \%)$.

In terms of total investment capital, once again manufacturing accounted for lion's share (33.03\%) followed by agriculture $(20.73 \%)$, real estate renting and business activities (14.85\%) and constriction $(12.89 \%)$.

The licensed investment project in the manufacturing sector are expected to create $32.3 \%$ of the total permanent employment to be followed by agriculture $(31.58 \%)$, real estate, renting and business activities $(12.4 \%)$ and constriction (7.24\%). Regarding temporary employment, $62.2 \%$ is expected to be in agriculture, $13.2 \%$ in manufacture, $12.3 \%$ in construction and $6.09 \% \mathrm{n}$ real estate, renting and business activities .

\subsection{ECONOMETRICS ANALYSIS}

In chapter three all attempt has been made to see the Derg regime and post 1991 state of privet investment in Ethiopia along with macroeconomics environment with respect to certain variable. In this chapter due attention is given to econometrics analysis to identify the direction and significance of factors that determine private investment in Ethiopia. Although there are a number of explicit variable that determine private investment, this paper only includes factors for which appropriate data is available.

\subsubsection{Model specification}

In developing, an investment model is unable to include all the determinants of private investment due to unavailability of data required and unquantifiable of some of the determinants. Because of difficulty of identifying theoretical correct specification model of private investment, this paper does not attempt to build and estimate a full-scale structural model of private investment in Ethiopia.

Accordingly, real GDP, lending rate, consumer price index (inflation), private credit availability, public investment and market liberalization (dummy) are used as exogenous variables, which assumed to determine the private investment.

The model specified as follow:

$$
\begin{aligned}
& \mathrm{I}_{P}=f(R G D P, \operatorname{Inf}, r, P C A, \operatorname{Ig}, D M L) \\
& L I_{p}=\beta_{o}+\beta_{1} L R G P+\beta_{2} \operatorname{Inf}+\beta_{3} n r+\beta_{4} L P C A+\beta_{5} L I g+\beta_{6} D M L(\text { dummy })+e_{i}
\end{aligned}
$$

Where:

$$
\begin{array}{ll}
\checkmark & \beta_{0}=\text { Constant term } \\
\checkmark & \beta_{1}, \beta_{2}, \beta_{3}, \beta_{4}, \beta_{5} \text { and } \beta_{6} \text { are coefficient to be estimated }
\end{array}
$$


$\checkmark \quad L I_{P}=\log$ of private investment

$\checkmark \quad L \mathrm{RGP}=\log$ of real GDP

$\checkmark \quad \operatorname{Inf}=$ inflation

$\checkmark \mathrm{n} r=$ nominal lending rate

$\checkmark \quad L p c a=\log$ of private credit availability

$\checkmark \quad L I_{g}=\log$ of public investment

$\checkmark$ DML $=$ domestic market liberalization

$\checkmark \quad e_{i}=$ stochastic error term (socio economic and environmental factors)

\subsubsection{Variable description}

It is important to see why such explanatory variable are included and in what way they determine the dependant variable.

The first variable included as an explanatory variable is the real GDP. The level of output or income in the whole economy has an influence on private investment. As GDP increases income increases and consumption also increases. At the same time the market for product that produced by investor is increases (Seven and Solimano, 1992-1997). Thus, growth in GDP leads to an increase in private investment, so we expected a positive sign from GDP in the regression.

The second variable is consumer price index (Inflation). Inflation brings uncertainty in the future. Therefore, there is negative relationship between inflation and private investment (Akpalu, 1997).

Thirdly, leading interest rate directly reflects the costs of credit. Therefore, higher interest rate means higher costs of credit and vice versa. As a result, interest rate and private investment move in opposite direction: (Mankiw, 1995). This leads to an expectation of negative sign on lending interest rate in the regression.

The forth variable is credit availability to private sector. In Ethiopia where own saving is not sufficient to undertake investment activity, the availability of credit is the important factor that determine private investment. Empirical study by Shafik (1990) for Egypt has shown positive significant relationship between bank credit and private investment. On the account of this, the availability of credit to private sector is included to see the significance and direction of its effect in Ethiopian case. Here we expect positive relationship.

The fifth variable is a public investment. Public investment has a positive or negative effect on private investment. Directly or indirectly, public investment had drawn funds that would otherwise have been available to finance private investments. This situation, crowd out private investments. On the other hand, public investment in public health, communications, and other infrastructure is a complementary form of investment that long-term stimulating effects on private investment. Public investment may also encourage private investment by increasing income and there by demand. (Pfeffermana and Madarssy, 1993: Pp 7)

Finally, domestic market liberalization, which reflects the regime, is assumed to determine the private investment. It has been argue that during the Derg era, there was discrimination of private sectors. Nevertheless, with coming of EPRDF, all the discriminatory elements that were embodied in policy of the military regime were eliminated through policy reforms. Some of the policy variable cannot be captured quantitatively. Accordingly, dummy variable with value of zero before 1990(pre-reform) and with value of one after 1991(post reform) is taken. Here positive sign is expected because the reforms are expected to encourage private investment.

Table 3.1 Result of log least Square Method

\begin{tabular}{|l|l|l|l|l|}
\hline Variable & Coefficients & SE & t-value & $\mathrm{P}>|\mathrm{t}|$ \\
\hline Cons. & -.0011323 & .0581494 & -0.02 & 0.985 \\
\hline LogRGDP & 1.63647 & .5670533 & 2.89 & $0.009^{*}$ \\
\hline LogPCA & .4478107 & .1214722 & 3.69 & $0.001^{*}$ \\
\hline LogIg & -.5408215 & .2515135 & -2.15 & $0.043^{* *}$ \\
\hline LogCPI & -.3671056 & .4094596 & -0.90 & 0.380 \\
\hline R & -.0006088 & .0210198 & -0.03 & 0.977 \\
\hline DML & .034717 & .0719938 & -0.73 & 0.472 \\
\hline Res & -1.639357 & .2585324 & -6.34 & $0.000^{*}$ \\
\hline
\end{tabular}

$\mathrm{F}(9,22)=12.39$

R-squared $=0.8352$

Adj R-squared $=0.7677$

An attempt has been made to apply log linear OLS method because of some of differential advantage, but the result was not that much satisfactory as three of the coefficients of the variable were found to be in 
significant.

Using functional form the standard regression may be written as:

\section{$\log I p=-0.0011+1.636 \log R G D P+0.448 \log P C A-0.541 \log I g-0.367 \log C P I+0.0006 r \quad-0.034717 \mathrm{dml}$}

The coefficient measures the marginal contribution of the independent variables to the dependent variable, holding all other variables fixed.

When we starts our interpretation from constant value that means -0.0011 , it assumes that it is presented when the other entire independent variable are zero. That is when all the other explanatory variables are constant the private investment is decreased by $0.1 \%$.

In this model, most the explanatory variables are confirmed with sign what we mentioned in the variable description sections.

In this model, the expected result is found on the relationship between GDP and private investment, which is positive. The coefficient shows that a $1 \%$ increase in GDP results an increase in private investment by $163.6 \%$. This implies that private investment highly responds to GDP or national output changes. In most cases in Ethiopia, GDP is the important significant explanatory variable in determining private investment. This is due to it create market for product that produced by private investors. Akpalu W., (1997) and Seve Solimano, (1992), found the same result.

The credit availability for private sector has a direct effect on private investment, which is the same as expectation. Accordingly, a $1 \%$ increase in credit availability the private investment increases by $44.8 \%$. In Ethiopia where own saving is not sufficient to undertake investment activity, the availability of credit is the important factor that determine private investment. The result coincides with Shafik (1990).

As shown from the result the sign of public investment is negative and it is significant at $5 \%$ level. Thus, the relationship between public investment and private investment is inversely related which shows that public investment crowd out the private investment. In the short run, government spending using up financial and other resources that would otherwise be used by private sectors affect the private investment to reduce. As such, 1\% increases in public expenditure reduce the private investment by $54 \%$.

Consumer price index (inflation) has expected result. That means, the CPI and private investment has negative relationship. As a result, from this model a 1\% increase in CPI insignificant leads to $36.7 \%$ decrease in private investment. However, the explanatory variable is. This might be due to rational expectation.

When we look in cases of lending rate, it has opposite relationship with that of private investment, this is why it shows negative sign when we regress it. Generally, based on data that researcher found from different sources shows that in past 35 years in Ethiopia the interest rate have opposite relationship with private investment. When we show this in a numerical way a $1 \%$ increase in lending rate leads to $0.06 \%$ decrease in private investment. Eventually, this explanatory variable is not significant because of most of the nations take place investment activity not by borrowing from financial institutions rather from either personal capital or borrowing from their friends. Even if there were financial availability, due to their high lending rate for an investor, they would not want to borrow from them. This is similar to those found by Mankiw, (1995).

In the final case, the expectation is found on the relationship between domestic market liberalization (DML) and private investment past 35 years. According to these model findings, the domestic market liberalization has strong effect on private investment than the other. This is mainly because of private investment during the Derg regime restricted to involve in investment, which means there were no market liberalization.

To make things in brief the other parts of this model must be interpreted. The standard error (SE) column reports the estimated SE of the coefficient estimate. To be significance variable, the estimated coefficient of the explanatory variable should less than the SE. Here the $\log$ (RGDP), Log (PCA) and $\log (\operatorname{Ig})$ are fulfilled this rule.

A formal test is given by the t-test. In each case, it provides the t-value for a test that the specified coefficient is zero. For the significance just observe the $\mathrm{p}$-value (which appears below $\mathrm{P}>|\mathrm{t}|$ ). For the constant, $\log (\mathrm{CPI}), \mathrm{r}$ and DML we obtain a $\mathrm{p}$-value of $0.985,0.38,0.977$ and 0.472 respectively, which means that, they are not significant at any useful significance level. However, the slope coefficient of log (RGDP), Log (PCA) and $\log (\operatorname{Ig})$ have a p-value of $0.009,0.001$ and 0.043 which means they are significant at $1 \%, 5 \%$ and $10 \%$ significance level respectively.

In other case in the model, $83.5 \%$ successfully the explanatory variable can predict the dependent variable, which explain by R-squared. To shows, purely fitting model we used adjusted R-squared 76.77\%.

To sum up, we have seen that all the variable are specified in the model, with the exception of CPI, $r$ and DML, are highly significance in determining private investment. Hence, through econometrics analysis has not been complete and exhaustive including all the variables that determine private investment in Ethiopia. It would certainly help as to identify the sum of most important determinant of investment in Ethiopia. 


\section{Conclusion and Recommendation \\ 4.1 Conclusion}

In Ethiopia private investment has passes through different stages in which in same cases it was given due attention and in other it was seen as constraints to the will being of the economy.

Accordingly, the private investment policy of the Derg regime discourages private investment through abolition of private ownership (nationalization), through high interest rate. In this period much concerning were given to public investment. As result, the lowest level of private investment is regarding during this period.

Actually, existing of private investment where only small and to some extent of medium scale levels. There was no large-scale private investment since it was prohibition by law. Because of this, the economy damaged seriously. Because government was putting too much restrictions on private investments, the econometrics model shows that a positive relationship between DML and private investments which in contrast to this.

However, after the collapse of the Derg regime in 1991, attempts being made to recover the strength and dominance of private investment through various police measurement, which eliminate discriminations against the private investment. In addition, conducive environment were created in the economy for private investment by establishing the EIA under the investment proclamation NO. 37/1996.

According to the economic estimation, public investment crowds out private investment. This is due to the government draws funds, which is available for the private sector. Moreover, over half of the sample period public investments put on non-productive activities like military expenditure and even in the post reform situation the huge government expenditure following border conflict with Eritrea and the 2005 election can support the estimation.

Furthermore, private investment respond to all of the determinants on the theoretically expectation. Private investors seem positive responsive to GDP, PCA and DML, since they provide incentive to private investment. On the other hand, private investment negatively related with lending interest rate and CPI since they provide discouraging factors for private investment.

\subsection{Recommendation}

The commitment of current Ethiopian government in enhancing private sector is appreciable. It is this government commitment in improving the regulatory policy that has contributes for the significance growth of the private sector at national level. But given the fact that the country still lies at the bottom occupying among the least rank in terms of development much has to be done further to facilitate the participation both domestic and foreign investors so that they make the largest contributions to the capital accumulation effort of the e economy.

Based on finding of this research for attracting and encouraging private investment in Ethiopia more than the current trend, the following possible suggestions are forwarded:

* Investment promotions have able to provide all the necessary information for potential investors and different promotion activity have to be done on regular bases to attract potential investors.

* The government should avoid unfavorable business climate including reluctant ness in implementation of economic reform programs and bureaucracies that hinder more toward implementation of investment projects and eye-catching incentive should be given to those private investors starting their projects write way.

Government should have to provide more incentive packages and encourage investors who invest at distance places from the center that come equally compensate for the advantage that they can get at the central parts o f the country.

* Rather than restricting the role of the government in economic affairs the government should provide public infrastructures which equally distributed throughout all parts of the country, so that all the business community and the society at large has been benefited accordingly.

* The government should utilize it s experts to generate detailed feasibility studies on various profitable projects and make this studies only and equally available to the business class to remove the weakness of private sector in identifying profitable business opportunities.

* Lastly but not the least, the financial institution (both the government and private) have to improve their policy of credit availability for private sector, so that the newly emerging business community will have better access to financial services.

\section{Bibliography}

- Addis A. (2005), Tends and Constraints of Private Investment in Ethiopia, Mage Printers Addis Abeba.

- Akpalu W. (1997) Determinates of Private Investment in Ghana ,Msc thesis; Addis Ababa

- Alemayehu Seyoum, Eta'al (2002), Ethiopian Economic Association, EEA volume1, Addis Ababa, Ethiopia.

- Befekadu and Berhanu Nega, (0999), Annual Report on Ethiopian Economy, United printer's, Addis 
Ababa.

- Befkadu, Eta'al (1994), strategies and macroeconomic policies for the development of private sector in Ethiopia, in the proceedings of third annual conference on Ethiopian economy Addis Ababa, Ethiopia.

- Dorm Busch R., eta'al (1990) constraints of private investment decision in developing countries. The Hague.

- Dorm Busch R., (2004), Microeconomics, McGraw-Hill published company Massachusetts Institute of Technology.

- $\quad \operatorname{EPRDF}(1992)$ proclamation No $15 / 1992$

(1996) proclamation No. 73/1996

(1998) proclamation No.196/1998

(1999) proclamation No.168/1999

(2002) proclamation No.280/2002

Ethiopia investment authority,(1998), annual report

Ethiopian investment commission, (2004), static is on investment in Ethiopia cumulative and trend (1992-2004), Addis Ababa, Ethiopia.

Girma S. (1994) Ethiopia private sector under structural adjustment, in proceeding of the third annual conference on Ethiopian economy. Addis Ababa, Ethiopia

$\checkmark$ Guy.P. preffermann and Andrea Madorassy (1993), 1990-91 editions. Trend in private investment in developing countries, international financial corporation discussion paper, 11

Gujarat w. (1995), basic econometrics, united stases of military academy, West point, third edition.

- Gwitterez M., (2005), Economic Growth in Latin America, Role of investment in and other ground sources, Santiago UN.

- Hashim K.M., (2003), Private Investment its Role in Ethiopian company and Constraints it faces post 1991, United printers, Addis Abebe

- Hajila T.N., (2001), History of economy thought, $16^{\text {th }}$ revised edition.

- Hiywot B. (1995), budget deficit and private investment in Ethiopia, AAU, Ethiopia.

- Hussein S. (1993), constraint on business development in Ethiopia and some measurement towards the solution, Addis Ababa chamber of commerce paper presented at the workshop on key business concept and negotiation skills for running successful business organized by investment office of Ethiopia and UNDP, Addis Ababa, Ethiopia.

- Jorgenson M. (1967), the theory of investment behavior, national bureau of economics research, Robert Feber edition, London.

- Keyemisrak, (1994), private sector development in Ethiopia, in the proceedings of the third annual conference on economy, Addis Ababa, Ethiopia.

- Keynes (1936), The General theory of employment, interest and money, Santiago, Harcourt brace Jovanovich.

- Lawerence Bouton and Mardiust A. sumlinsiki, (...) Trend in private investment in developing countries static's for 1970-1998, IFC, discussion paper 41.

- Mankiw D.N., (2000), Macroeconomics, $2^{\text {nd }}$ edition, Harvard University

- Report on Ethiopia economy, (2003/04), written by a team of experts in Ethiopia economic policy research institute and external consultant and advisor, Addis Ababa.

- Samson G/Michael and Tadele F., (2002), Ethiopian Economy, Mega printers, Addis Abeba

- UNDP, (2002), Investment and innovation policy review Ethiopia, united nation.

- World book, Encyclopedia (1992) Chico goes scoit Fetze Company. 